ISSN: 1858-4837; E-ISSN: 2598-019X

Volume 16, Nomor 2 (2021),

https://jurnal.uns.ac.id/region

DOI: $10.20961 /$ region.v16i2.47698

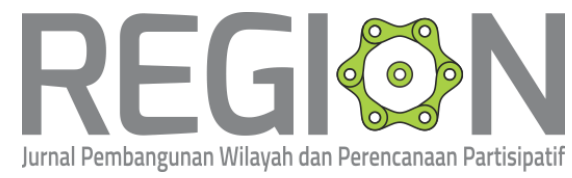

\title{
Konsep kota hijau dan peningkatan ketahanan kota di Indonesia
}

\author{
Green city concept and increasing resilience of cities in Indonesia
}

\author{
M Fuady \\ ${ }^{1}$ Prodi Arsitektur, Fakultas Teknik, Universitas Syiah Kuala, Banda Aceh, Indonesia
}

Corresponding author's email: mirzafuady@unsyiah.ac.id

\begin{abstract}
Abstrak. Sebagai upaya mengatasi berbagai persoalan kota seperti semakin berkurangnya ruang terbuka hijau akibat meningkatnya ruang terbangun dalam kota, beberapa kota di Indonesia termasuk kota Banda Aceh sudah menerapkan konsep Kota Hijau. Implementasi konsep Kota Hijau yang berbasis lingkungan menuntut kesiapan pemerintah dan warga kota untuk saling berpartisipasi mendukung konsep Kota Hijau yang diharapkan berdampak positif meningkatkan ketahanan kota. Namun keberhasilan penerapan konsep ini membutuhkan keseriusan pemerintah kota dalam membuat kebijakan pro lingkungan dan keaktifan peran komunitas hijau yang hidup dalam masyarakat. Untuk itu penelitian ini dilakukan dengan tujuan untuk mengetahui dan mendeskripsikan penerapan konsep Kota Hijau di Indonesia dan dampaknya dalam meningkatkan ketahanan kota. Penelitian ini menggunakan metode deskriptif kualitatif dalam mengumpulkan dan menganalisis data terkait implementasi konsep Kota Hijau di Indonesia. Hasil penelitian menunjukkan bahwa konsep Kota Hijau secara umum memberikan keuntungan bagi masyarakat dengan makin meningkatnya kuantitas dan kualitas ruang terbuka hijau dalam kota. Meskipun konsep Kota Hijau belum seutuhnya berhasil diwujudkan oleh pemerintah kota di Indonesia namun penyempurnaannya terus dilakukan secara berkesinambungan. Sinergi dari kebijakan pemerintah dan peran masyarakat secara sistematis dan konsisten dalam menerapkan atribut hijau dalam konsep Kota Hijau berdampak positif bagi ketahanan dan keberlanjutan kota.
\end{abstract}

Kata Kunci: Atribut Hijau; Ketahanan Kota; Kota Hijau

Abstract. In an effort to overcome various urban problems such as the decreasing green open space due to the increase in built-up space in cities, several cities in Indonesia including the city of Banda Aceh have implemented the Green City Concept.

Received: January 16, 2021; Accepted: February 10, 2021 Available online: July 15, 2021

Copyright $\odot$ 2021, REGION: Jurnal Pembangunan Wilayah dan Perencanaan Partisipatif 
The implementation of the Green City Concept which is environmentally-based demands the readiness of the government and city residents to mutually participate in supporting the Green City Concept which is expected to have a positive impact on increasing the resilience of the city. However, the success of implementing this concept requires the seriousness of the city government in making pro-environment policies and the active role of green communities. For this reason, this study was conducted with the aim of knowing and describing the application of the Green City Concept in Indonesia and its impact in increasing urban resilience. This study used a qualitative descriptive method in collecting and analysing data related to the implementation of the Green City Concept in Indonesia. The results showed that the concept of a Green City in general provides benefits to the community by increasing the quantity and quality of green open space in the city. Although the concept of a Green City has not been fully realized by the city government in Indonesia, its improvements are continuously being made. The synergy of government policies and the role of the community systematically and consistently in implementing green attributes in the Green City concept have a positive impact on the resilience and sustainability of the city.

Keywords: Green Attribute; Green City; Resilience City

\section{Pendahuluan}

Dinamika pertumbuhan penduduk kota dengan berbagai aktivitasnya telah mempengaruhi ketersediaan ruang terbuka hijau dalam kota. Dampak dari berbagai kegiatan ekonomi dan sosial di antaranya adalah tingginya kebutuhan penggunaan lahan terbangun sehingga ruang terbuka alami dalam kota menjadi semakin berkurang. Kecenderungan perkembangan kota ini tidak hanya terjadi di pusat kota tetapi juga meluas hingga daerah pinggiran kota dan wilayah sekitarnya, dimana seiring dengan peningkatan jumlah penduduk, maka meningkat pula kebutuhan pembangunan sarana dan prasarana kota untuk melayani kebutuhan warga kota.

Pembangunan dengan mengambil alih ruang terbuka hijau yang ada untuk diubah menjadi lahan terbangun, mengakibatkan berkurangnya ketersediaan ruang terbuka hijau dalam kota. Konsekuensi dari perkembangan kota yang mengabaikan ketersediaan ruang terbuka hijau akan berakibat timbulnya berbagai permasalahan lingkungan dan dampak negatif lainnya, seperti perubahan suhu, banjir, serta polusi. Perubahan suhu dalam kota merupakan suatu fenomena yang terjadi pada suatu wilayah kota yang padat dimana suhunya lebih tinggi dibandingkan suhu udara pada bagian kota yang memiliki banyak ruang terbuka hijau. Fenomena yang dikenal dengan nama Urban Heat Island (UHI) ini sering terjadi pada wilayah padat bangunan yang hanya memiliki sedikit ruang terbuka hijau sementara ruang terbuka yang ada umumnya menggunakan material penutup permukaan tanah, seperti jalan aspal dan lantai beton [1].

Selain persoalan yang telah disebut di atas, berbagai masalah perkotaan lain juga dapat timbul dan mengganggu kehidupan masyarakat. Persoalan tersebut antara lain adalah menurunnya 
kualitas udara, meningkatnya polusi akibat kemacetan lalu lintas, menurunnya kenyamanan dalam lingkungan kota, dan krisis sumber daya air. Untuk mengatasi permasalahan tersebut, konsep Kota Hijau dapat menjadi alternatif solusi yang diharapkan mampu menjawab persoalan kota sekaligus meningkatkan ketahanan kota demi terwujudnya kehidupan kota yang berkelanjutan secara ekonomis, sosial budaya, dan ekologis [2].

Beberapa kota di Indonesia telah menerapkan konsep Kota Hijau dalam perencanaan pembangunan serta peremajaan kawasan tertentu dalam kota. Misalnya, Kota Bandung yang mengusung konsep Kota Hijau dengan peningkatan kualitas ruang terbuka hijau kota berupa taman-taman tematik [3]. Begitu pula Kota Bogor yang telah merencanakan penataan lanskap yang khas sebagai upaya menguatkan citra identitas Kota Bogor sebagai Kota Hijau [4].

Selain dengan menerapkan atribut hijau dalam perencanaan kota, konsep Kota Hijau juga bertujuan untuk menambah besaran luasan ruang terbuka hijau dalam kota seperti yang dilakukan oleh pemerintah Kota Semarang [5] dan pemerintah Kota Sragen dengan mengoptimalkan jalur hijau tepi jalan dan sungai [6]. Hal serupa juga dialami oleh Kota Banda Aceh, yang telah menerapkan konsep Kota Hijau sejak tahun 2011. Pemerintah Kota Banda Aceh terus mengoptimalkan keberadaan ruang terbuka hijau dalam kota sebagai upaya menjadikan Kota Banda Aceh yang berkelanjutan pasca bencana tahun 2004 [7].

Secara umum penerapan konsep Kota Hijau yang berbasis lingkungan menuntut kesiapan pemerintah dan warga kota untuk saling berpartisipasi dalam mewujudkan Kota Hijau yang ramah lingkungan dan diharapkan berdampak positif meningkatkan ketahanan kota. Namun, keberhasilan dalam menerapkan konsep Kota Hijau ini membutuhkan keseriusan pemerintah kota dalam membuat kebijakan pro lingkungan dan keaktifan peran masyarakat dalam komunitas hijau. Berdasarkan uraian di atas, maka rumusan masalah dalam penelitian ini adalah bagaimana penerapan konsep Kota Hijau di Indonesia dan dampaknya dalam meningkatkan ketahanan kota. Adapun tujuan penelitian ini adalah untuk mengetahui dan mendeskripsikan penerapan konsep Kota Hijau di Indonesia dan dampaknya dalam meningkatkan ketahanan kota.

\section{Metode}

Penelitian ini menggunakan pendekatan kualitatif deskriptif dalam melakukan kajian literatur terkait implementasi konsep Kota Hijau di beberapa kota di Indonesia dan menjadikannya sebagai rujukan dalam memahami penerapan konsep Kota Hijau di Indonesia dan dampaknya dalam meningkatkan ketahanan kota. Data kajian literatur bersumber dari dokumen resmi pemerintah, artikel jurnal, laporan penelitian, dan sumber-sumber lain yang relevan dan terpercaya. Selain itu, pengumpulan data juga dilakukan dengan melakukan observasi lapangan terkait dengan penerapan elemen dari atribut hijau di Kota Banda Aceh. 


\section{Hasil Penelitian dan Pembahasan}

\subsection{Implementasi konsep kota hijau di Indonesia}

Konsep Kota Hijau merupakan sebuah gagasan untuk mewujudkan kota yang ramah lingkungan, dengan memanfaatkan sumber daya air dan energi secara efisien dan efektif, mengurangi jumlah limbah dan meningkatkan kesehatan lingkungan, serta mengoptimalkan lingkungan alami dan buatan, sesuai dengan prinsip pembangunan berkelanjutan [2]. Untuk itu, gagasan mewujudkan sebuah kota menjadi Kota Hijau memiliki makna strategis yang didasarkan atas pertimbangan pertumbuhan kota yang begitu pesat dapat berdampak timbulnya berbagai persoalan perkotaan, seperti kondisi permukiman yang kumuh, kemacetan, kesenjangan secara sosial, banjir, dan minimnya ketersediaan ruang terbuka hijau perkotaan. Persoalan tersebut akan semakin sulit dihadapi oleh pemerintah kota dengan munculnya fenomena perubahan iklim, yang menuntut persiapan secara lebih seksama dan komprehensif serta realistis sebagai solusi terhadap perubahan yang terjadi secara global [8]. Konsep Kota Hijau di Indonesia, dirintis oleh Direktorat Bina Penataan Bangunan Kementerian PUPR lewat Program Pengembangan Kota Hijau (P2KH) [9]. Program ini didukung dengan Rencana Aksi Kota Hijau (RAKH) yang berbasis menata ruang dalam mengembangkan wilayah, dengan kerangka pikir kota yang berkelanjutan dan kemandirian, serta peran provinsi dan pemerintah pusat dalam koordinasi agar program terus berlanjut.

Konsep Kota Hijau di Indonesia dalam penerapannya telah direncanakan sebagai wujud dari penjabaran UUPR Nomor 26 tahun 2007 terutama berkaitan dengan pemenuhan dan penyediaan lahan untuk ruang terbuka hijau. UU No. 26 tahun 2007 [10] tersebut mengamanatkan perwujudan $30 \%$ dari luas wilayah kota sebagai ruang terbuka hijau (RTH) dengan porsi $20 \%$ berupa ruang terbuka hijau publik (RTH Publik) dan $10 \%$ berupa ruang terbuka hijau privat (RTH Privat). Program Kota Hijau akan memberikan keuntungan bagi pemerintah dan warga kota dengan meningkatnya kualitas dan kuantitas ruang terbuka hijau sehingga dapat menjaga ekosistem lingkungan serta meningkatkan kualitas lingkungan perkotaan menjadi lebih bersih, sehat, nyaman, dan indah [9].

Program Pengembangan Kota Hijau telah memperoleh tanggapan yang positif dari beberapa pemerintah dari kabupaten dan kota, dimana 60 Bupati/Walikota telah menandatangani Piagam Komitmen Kota Hijau pada saat memperingati Hari Tata Ruang yang berlangsung pada tanggal 7 hingga 8 November 2011, sebagai bentuk kesepakatan bersama untuk mendukung program Kota Hijau. Upaya mewujudkan sebuah Kota Hijau, dimulai dengan mengakomodasi target pencapaian luas ruang terbuka hijau minimal 30\% dari luas wilayah, dalam Rencana Tata Ruang Wilayah (RTRW) di setiap kabupaten/kota. Hal ini juga sesuai amanat UUPR No. 26 Tahun 2007 mengenai Penataan Ruang dalam mewujudkan ruang yang aman, nyaman, produktif, dan berkelanjutan [9].

Konsep Kota Hijau merupakan pengembangan dari konsep kota berkelanjutan, yang didasari prinsip pembangunan berkelanjutan dan kondisi nyata perkembangan kota, sehingga mampu menjawab kebutuhan perkotaan secara nyata sekalian menanggapi persoalan global perubahan iklim. Program Kota Hijau memiliki misi tidak hanya sekedar menghijaukan ruang 
kota, namun mencakup visi yang lebih besar dan menyeluruh, yaitu mewujudkan kota yang ramah lingkungan yang menggunakan secara efisien dan efektif sumber daya energi dan air, serta menurunkan jumlah sampah. Konsep ini juga memadukan sistem transportasi perkotaan, meningkatkan kualitas lingkungan yang sehat, dan mengoptimalkan lingkungan yang alami dan buatan berlandaskan prinsip pembangunan berkelanjutan dalam menjaga keseimbangan unsur lingkungan, social, dan ekonomi kota.

Terdapat delapan atribut hijau sebagai indikator dalam menghadirkan konsep Kota Hijau. Atribut pertama yaitu perencanaan dan perancangan hijau (green planning and design), dengan tujuan menaikkan mutu rencana tata ruang serta rancang kota agar lebih peka terhadap lingkungan alami, serta mencakup upaya adaptasi dan mitigasi terhadap perubahan iklim. Atribut kedua adalah ruang terbuka hijau (green open space) yang bertujuan untuk menaikkan mutu dan jumlah ruang terbuka hijau dalam kota sesuai dengan karakteristik kota, dengan target ketersediaan ruang terbuka hijau seluas 30\% dari besar wilayah kota. Adapun atribut ketiga adalah komunitas hijau (green community) yaitu mendukung berkembangnya jaringan kerjasama antara pemerintah, unsur warga, dan pengusaha yang peduli pada lingkungan kota yang sehat.

Selanjutnya, atribut keempat adalah meminimalkan upaya mengolah limbah dan sampah (green waste), dengan mengaplikasikan zero waste. Atribut yang kelima yaitu mengembangkan sistem transportasi yang terus berlanjut (green transportation) yang mengajak masyarakat agar memakai moda transportasi umum yang ramah lingkungan, serta aktif berjalan kaki serta bersepeda dalam lingkungan dengan jarak tempuh yang terbatas. Adapun atribut yang keenam yaitu meningkatkan kualitas air (green water) dengan mengaplikasikan gagasan zero run-off dan eko drainase. Atribut yang ketujuh yaitu menggunakan secara efisien sumber energi yang ramah lingkungan (green energy). Terakhir, atribut kedelapan adalah penerapan bangunan hijau (green building) yang hemat energi [9].

Menurut Ernawi [2], semua atribut Kota Hijau tidak saling terpisah, namun menjadi bagian yang menyatu, termasuk dalam hubungannya dengan memajukan ekonomi setempat sebagai efek lanjutan dari kehadiran setiap atribut. Beberapa atribut hijau seperti green transportation, green waste, green energy, green water, dan green building terkadang disebut juga dengan istilah infrastruktur hijau (green insfrastructure).

Implementasi atribut hijau oleh pemerintah kota yang menerapkan konsep Kota Hijau dalam kenyataannya tidak merata, dimana sebagian atribut dapat terlihat lebih dominan dibandingkan atribut hijau lainnya. Menurut Amira [11], dari hasil evaluasi yang dilakukan terhadap penerapan delapan atribut kota hijau di Kota Jakarta, diperoleh hasil yang lebih menonjol pada atribut transportasi hijau, ruang terbuka hijau serta perencanaan dan perancangan hijau. Hal ini selaras dengan rencana pengembangan transportasi massal yang menjadi fokus utama pemerintah Kota Jakarta. Sementara keberadaan ruang terbuka hijau dalam Kota Jakarta semakin membaik secara kualitas namun sulit dalam pemenuhan ruang terbuka hijau secara kuantitas akibat semakin langka dan mahalnya lahan di Kota Jakarta. 
Sementara itu menurut Kusuma, dkk [1], Kota Surabaya sebagai kota terbesar nomor dua di Indonesia dengan jumlah penduduk yang besar dan penggunaan lahan terbangun yang terus meningkat, juga telah merasakan ancaman perubahan iklim berupa banjir dan peningkatan suhu dalam lingkungan kota. Sebagai upaya antisipasi untuk menanggulangi permasalahan tersebut, Pemerintah Kota Surabaya telah menerapkan konsep Kota Hijau dengan delapan atribut hijau yang harus dipenuhi. Dalam tahapan awal yang dilakukan adalah fokus pada tiga atribut utama, yaitu perencanaan dan perancangan hijau, ruang terbuka hijau, dan komunitas hijau.

Pemerintah Kota Surabaya telah menerapkan atribut perencanaan dan perancangan hijau dalam Perda Nomor 12 tahun 2014 tentang RTRW Kota Surabaya untuk tahun 2014 hingga 2034 [12]. Begitu pula ketersediaan ruang terbuka hijau publik dalam Kota Surabaya telah mencapai $21,79 \%$ dari luas wilayah Kota Surabaya atau setara dengan 7.290,53 ha. Sementara dalam pembinaan komunitas hijau, telah banyak terbentuk komunitas peduli lingkungan di Kota Surabaya, dimana di antaranya aktif melakukan program peduli lingkungan yaitu HiLo Green Community Surabaya, Earth Hour Surabaya, dan Sea Soldier Surabaya [1].

Sementara itu Pemerintah Kota Banda Aceh juga telah menunjukkan penerapan atribut hijau dalam implementasi konsep Kota Hijau di Kota Banda Aceh yang terlihat dari telah ditetapkannya Qanun RTRW Kota Banda Aceh tahun 2009-2029 yang menyebutkan pentingnya ketersediaan ruang terbuka hijau publik sebesar minimal $20 \%$ dari luas wilayah Kota Banda Aceh [13]. Untuk itu pemerintah kota harus dapat menambah ketersediaan ruang terbuka hijau setiap tahunnya sesuai rencana hingga tahun 2029. Beberapa atribut hijau lain juga telah diterapkan di Kota Banda Aceh seperti: (a) transportasi hijau dengan telah berjalannya Bus Transkutaraja sebagai upaya mengurangi penggunaan kendaraan pribadi; (b) pengelolaan sampah yang semakin baik terlihat dari semakin bersihnya suasana kota; (c) penyediaan air bersih yang semakin baik dimana layanan air semakin lancar dan konsisten melayani kebutuhan warga; dan (d) terbentuknya komunitas hijau di kawasan hutan kota Tibang dan Peulanggahan.

Menurut Ekaputra dan Sudarwani [14], atribut hijau juga sudah diaplikasikan dalam perencanaan taman ramah lingkungan sesuai Program Pengembangan Kota Hijau (P2KH) di Kota Semarang, seperti terlihat pada: (a) rancangan taman pada kawasan Rejomulyo dan lahan eks Pasar Sampangan; (b) peningkatan peran masyarakat dengan membentuk komunitas hijau dari warga setempat sehingga taman berperan optimal menjadi tempat interaksi sosial; dan (c) penggunaan sistem transportasi yang terus berlanjut, yang diterapkan dalam memberikan kemudahan dan kenyamanan untuk diakses dalam bentuk jalur pejalan kaki di tepi jalan dan dalam taman serta disediakannya jalur sepeda dan parkirnya.

Sementara itu, menurut Susilowati dan Nurini [15], Kota Surakarta juga telah menerapkan konsep Kota Hijau di antaranya dengan cara optimalisasi fungsi ruang terbuka hijau di permukiman padat seperti: (a) pekarangan rumah tinggal yang difungsikan sebagai tempat interaksi skala keluarga; (b) halaman perkantoran, pertokoan, dan tempat usaha yang dapat digunakan sebagai ruang parkir terbuka, dan area untuk menyelenggarakan berbagai kegiatan 
ruang luar seperti, senam, bazar, dan lain-lain; (c) taman atap bangunan yang dapat difungsikan sebagai tempat interaksi skala keluarga atau rumah tangga; (d) pengembangan ruang terbuka hijau untuk pejalan kaki sekaligus digunakan menjadi ruang sosial untuk berlangsungnya interaksi antar warga secara aktif ataupun pasif serta menjadi elemen alami penyeimbang suhu, penyaring emisi kendaraan, dan keindahan visual.

\subsection{Konsep kota hijau dan ketahanan kota}

Menurut Fuady, dkk. [7] terkait ketangguhan kota menghadapi bencana maka konsep ketahanan kota harus direncanakan untuk merespon berbagai kemungkinan perubahan yang dapat terjadi dalam lingkungan kota, baik perubahan gradual yang lambat ataupun kejadian cepat yang mampu melumpuhkan fungsi kota. Gangguan dan ancaman terhadap kota pada akhirnya akan berdampak negatif terhadap masyarakat kota, khususnya mereka yang tergolong rentan. Ketidakpastian besar dan lamanya sebuah gangguan harus diperhitungkan sebagai sebuah persiapan dan kalau terjadi gangguan maka dapat cepat diambil tindakan sehingga risiko yang timbul akan lebih sedikit. Sehubungan dengan konsep kota hijau, maka ketahanan kota juga dapat disimulasikan terhadap berbagai kemungkinan ancaman dan gangguan, termasuk merespon dampak perubahan iklim.

Konsep Kota Hijau merupakan suatu terobosan konsep perkotaan di Indonesia yang pro lingkungan sekaligus dapat menjawab tantangan global di masa depan. Sebagai konsep kota yang ramah lingkungan, gagasan ini juga diharapkan berdampak positif bagi masyarakat dengan mengembangkan daya tahan warga serta pemerintah setempat. Ketahanan kota dalam konsep Kota Hijau juga dapat dikaitkan dengan konteks upaya mitigasi dan adaptasi terhadap tantangan perubahan iklim [8].

Perubahan iklim telah menjadi sebuah persoalan mendesak bagi banyak kota di berbagai bagian dunia, khususnya negara yang berkembang, dimana pertumbuhan penduduk perkotaan telah meningkat dengan cepat. Perubahan iklim menjadi ancaman yang dapat meningkatkan kerentanan fisik dan sosial, menghancurkan kegiatan ekonomi, serta menghalangi pembangunan. Golongan masyarakat miskin di perkotaan akan menerima pengaruh paling besar, karena golongan ini tinggal dan bekerja di lingkungan permukiman informal yang rawan terpapar oleh ancaman tersebut.

Terkait ancaman perubahan iklim, beberapa kota besar di Indonesia, seperti Jakarta dan Semarang telah merasakan dampaknya berupa ancaman banjir akibat naiknya permukaan air laut [16]. Beberapa lokasi di pesisir Kota Jakarta diperkirakan akan tergenang akibat naiknya permukaan air laut yang meningkat $0,57 \mathrm{~cm}$ per tahun, sementara itu juga diprediksi terjadi turunnya muka tanah dalam ukuran $0,8 \mathrm{~cm}$ per tahun. Kondisi ini berefek besar terhadap prasarana kota dan produktivitas ekonomi kota [8].

Untuk itu pemerintah kota harus berinisiatif membentengi diri terhadap efek perubahan iklim baik untuk masa sekarang maupun waktu yang akan datang dengan memperhitungkan kekuatan dan parahnya dampak yang akan terjadi. Pemerintah kota seperti Jakarta yang telah memiliki rencana ketahanan kota berarti telah menyiapkan kotanya sebagai kota yang 
tangguh [17]. Meskipun kepastian terjadinya suatu bencana sulit diprediksi, namun dampak yang akan terjadi dapat diprediksi, sehingga sebuah kota menjadi tangguh dan mampu mengatasi bencana secara cepat dan tepat, dengan cara yang efisien dan efektif [18]. Sehubungan dengan itu, gagasan rencana membangun ketangguhan kota menghadapi persoalan perubahan iklim menjadi penting didahulukan oleh pemerintah kota.

Menurut Fuady, dkk [19], keberadaan ruang terbuka hijau sebagai salah satu atribut dalam konsep Kota Hijau berperan penting dalam mendukung ketahanan kota khususnya yang terkait dengan fungsi ekologis ruang terbuka hijau dalam hal penyediaan oksigen, penyimpan air dan penyerap karbon dioksida. Dengan tersedianya berbagai pohon besar dalam ruang terbuka hijau hutan kota, maka secara alami hutan kota akan menghasilkan oksigen saat proses fotosintesis berlangsung di siang hari. Begitu pula dengan ketersediaan air tanah, semakin luas ruang terbuka hijau dalam kota maka semakin besar peluang tanaman dalam ruang terbuka hijau menyerap dan menyimpan air tanah serta mencegah terjadinya genangan air dan banjir. Selanjutnya pepohonan dalam ruang terbuka hijau juga berfungsi menyerap karbon dioksida dari buangan kendaraan bermotor sehingga menurunkan tingkat polusi udara dalam kota.

Adapun aspek mitigasi dalam perubahan iklim mencakup berbagai usaha yang disiapkan untuk meminimalkan polusi rumah kaca. Selain itu, juga direncanakan upaya mitigasi dengan meningkatkan efisiensi pemakaian energi pada lingkungan terbangun dalam kota, meningkatkan pemakaian sumber energi pilihan lainnya, dan penggunaan sistem transportasi publik dengan sumber energi alternatif yang dapat menurunkan jumlah kendaraan milik pribadi.

Terkait aspek mitigasi bencana, keberadaan ruang terbuka hijau sebagai salah satu atribut konsep Kota Hijau memiliki peran penting dalam hal perlindungan dan penyelamatan jika terjadi bencana. Ruang terbuka hijau dalam bentuk bukit yang tinggi dapat menjadi daerah aman jika terjadi banjir dan ruang terbuka hijau yang luas dapat menjadi tempat evakuasi [20]. Begitu pula peran atribut energi hijau dan transportasi hijau jika telah diterapkan secara optimal maka akan berfungsi dalam upaya mitigasi mengurangi emisi gas rumah kaca dalam kota.

Terkait dengan ketahanan kota, selain merencanakan aspek mitigasi bencana, pemerintah kota juga harus memperhitungkan aspek adaptasi. Adapun aspek adaptasi dalam perubahan iklim meliputi berbagai upaya yang disiapkan untuk menurunkan tingkat kerentanan lingkungan kota dan masyarakat terhadap efek perubahan iklim. Contoh adaptasi dalam perubahan iklim dapat berupa peningkatan sistem drainase lingkungan untuk mengantisipasi meningkatnya debit limpasan air hujan, perencanaan dan pengendalian pemanfaatan ruang dan tata guna lahan, peningkatan sistem pengatur banjir, peningkatan ketersediaan pangan, pengurangan konsumsi air bagi rumah tangga dan industri, serta peningkatan penggunaan sumber air alternatif misalnya air hujan [8]. Tindakan-tindakan adaptasi ini perlu dukungan keterlibatan seluruh pemangku kepentingan dalam kota. 
Sejalan dengan peningkatan ketahanan kota, upaya pemerintah kota dengan menerapkan atribut perencanaan dan perancangan hijau serta peningkatan kualitas dan kuantitas ruang terbuka hijau dalam kota akan menurunkan tingkat kerentanan kota serta masyarakatnya terhadap efek perubahan iklim. Sebagai contoh kasus Kota Surabaya yang mengalami banjir di beberapa lokasi permukiman padat dan peningkatan suhu rata-rata di atas $32{ }^{\circ} \mathrm{C}$ dalam jangkauan wilayah yang luas yaitu sekitar $58,58 \%$ dari luas wilayah Kota Surabaya. Peningkatan suhu tertinggi terjadi di wilayah timur dan barat Kota Surabaya dimana umumnya tutupan lahan berupa wilayah terbangun. Untuk mengatasi persoalan tersebut, Pemerintah Kota Surabaya telah melakukan upaya yang berkaitan dengan optimalisasi dan penambahan ruang terbuka hijau [1].

\section{Kesimpulan}

Konsep Kota Hijau tidak hanya hadir sebagai rencana peningkatan luasan ruang terbuka hijau dalam kota, tapi juga untuk mendorong terwujudnya kebijakan pro lingkungan oleh pemerintah kota yang sekaligus dapat menjawab permasalahan ketahanan kota di masa yang akan datang. Keberhasilan pemerintah kota mengimplementasikan konsep Kota Hijau secara konsisten butuh komitmen masyarakat untuk mau merubah kebiasaan menjadi lebih hemat sumber daya alam, ramah lingkungan, dan tidak boros dalam penggunaan energi.

Dalam mengimplementasikan konsep Kota Hijau, pemerintah kota juga menghadapi berbagai tantangan, di antaranya adalah tingginya pembiayaan serta terbatasnya lahan dalam kota yang dapat dijadikan sebagai ruang terbuka hijau guna memenuhi target luasan $30 \%$ dari luas wilayah kota. Begitupula dalam aspek lingkungan, tantangan yang dihadapi adalah meningkatnya jumlah penduduk dalam kota sejalan dengan perubahan waktu yang mengakibatkan tingginya beban yang diterima oleh lingkungan dan orientasi pembangunan yang lebih mengedepankan kemajuan ekonomi dan lemah terhadap aspek lingkungan. Selain itu, juga masih ada tantangan dalam aspek sosial berupa rendahnya partisipasi masyarakat serta terbatasnya kerjasama dan koordinasi antar sektor dalam pengelolaan lingkungan hidup.

Keberhasilan program Pengembangan Kota Hijau mensyaratkan adanya pendekatan keberlanjutan, sejalan dengan rencana penataan ruang yang tidak hanya pada tataran perencanaan, namun terus berlanjut pada aplikasi rencana berbentuk tindakan nyata dalam lingkup wilayah kota sebagai suatu kesatuan yang lengkap. Program ini juga tidak hanya kumpulan kepentingan bagian sektoral, melainkan menjadi suatu bentuk program yang kolaboratif dan sinergis dengan pemerintah kota dan masyarakat sebagai pelopor utama serta didukung pemerintah pusat. Gerakan aksi kolaboratif tentunya tidak dapat muncul secara spontan, namun membutuhkan proses yang sistematis dan konsisten, dimulai dengan upaya sosialisasi, mobilisasi, persuasi, hingga penerapannya, agar harapan kesadaran gerakan kolektif yang sebenarnya dalam masyarakat dapat terwujud.

\section{Referensi}

[1] Kusuma RD, Purnomo EP, Kasiwi AN. Analisis Upaya Kota Surabaya Untuk Mewujudkan Kota Hijau (Green City). Din J IIm IImu Adm Negara 2020;7:13-27.

[2] Ernawi IS. Gerakan Kota Hijau: Merespon Perubahan Iklim dan Pelestarian Lingkungan. 
Bul Tata Ruang Badan Koord Penataan Ruang Nas 2012:4-7.

[3] dkk Sagala AR. Perencanaan Taman Kota sebagai Salah Satu Atribut Kota Hijau di Kecamatan Gedebage, Bandung. Vitr J Arsitektur, Bangunan, Lingkung 2017;6:85-90.

[4] Siregar MRA. Komunikasi Kota Ruang Publik Taman Sebagai Pembentuk Citra Kota Hijau. J Komun Pembang 2019;17:102-13. https://doi.org/10.29244/jurnalkmp.17.1.102113.

[5] Sudarwani MM, Ekaputra YD. Kajian Penambahan Ruang Terbuka Hijau di Kota Semarang. J Tek Sipil Dan Perenc 2017;19:47-56. https://doi.org/10.15294/jtsp.v19i1.10493.

[6] Al Habib RA, Qomarun Q. Identifikasi Atribut Green City Di Kota Sragen (Penekanan Pada Rth Jalur Hijau Dan Jalur Biru). Sinektika J Arsit 2014;14:149-57. https://doi.org/10.23917/sinektika.v1i1.1133.

[7] Fuady M, Buraida, Fuady MRF. Disaster preparedness collaboration between Banda Aceh and Japan. IOP Conf. Ser. Mater. Sci. Eng., vol. 1087, Banda Aceh: 2020, p. 12003. https://doi.org/10.1088/1757-899x/1087/1/012003.

[8] Parasati H. Kebijakan Perkotaan Terkait Perubahan Iklim. Bul Tata Ruang Badan Koord Penataan Ruang Nas 2012:15-8.

[9] Kementerian Pekerjaan Umum. Panduan Pelaksanaan Program Pengembangan Kota Hijau (P2KH). Jakarta: Direktorat Jenderal Penataan Ruang, Kementerian Pekerjaan Umum; 2011.

[10] Republik Indonesia. Undang-Undang Nomor 26 Tahun 2007 Tentang Penataan Ruang 2007.

[11] Amira. Evaluasi Penerapan Konsep Kota Hijau di Kota Jakarta. Institut Pertanian Bogor, 2014.

[12] Pemerintah Kota Surabaya. Peraturan Daerah Kota Surabaya Nomor 12 Tahun 2014 Tentang Rencana Tata Ruang Wilayah Kota Surabaya Tahun 2014-2034 2014.

[13] BAPPEDA Kota Banda Aceh. Inisiasi Kota Hijau Banda Aceh 2034. Banda Aceh: PT. Jasa Lingkungan Indonesia; 2014.

[14] Ekaputra YD, Sudarwani MM. Implikasi Program Pengembangan Kota Hijau P2KH terhadap Pemenuhan Luasan RTH Perkotaan. Pros. SNST ke-4, Semarang: Universitas Wahid Hasyim Semarang; 2013, p. 27-32.

[15] Susilowati I, Nurini. Konsep Pengembangan Ruang Terbuka Hijau (RTH) pada Permukiman Kepadatan Tinggi. J Pembangungan Wil Dan Kota 2013;9:429-38. https://doi.org/10.14710/pwk.v9i4.6680.

[16] Harjati P. Membangun Ketahanan Perkotaan terhadap Dampak Perubahan Iklim dan Risiko Bencana. Makal Dalam Lokakarya Perubahan Iklim Dan Kota Hijau 2011.

[17] Pemprov DKI Jakarta. Strategi Ketahanan Kota Jakarta. Jakarta: 100RC dan Rockefeller Foundation; 2019.

[18] Fuady M, Munadi R, Fuady MAK. Disaster mitigation in Indonesia: between plans and reality. IOP Conf. Ser. Mater. Sci. Eng., vol. 1087, 2020, p. 12011. https://doi.org/10.1088/1757-899x/1087/1/012011.

[19] Fuady M, Santosa HR, Soemardiono B. Ecological Green Spaces Needs for City of Banda Aceh. Proc. Int. Semin. Archit. Urban. Marit. Cult., Makassar: Universitas Hasanuddin; 
2013, p. G1--41.

[20] Mirza F. Disaster Mitigation Approach of Urban Green Structure Concept In Coastal Settlement. Dimens - J Archit Built Environ 2015;42:51-8. https://doi.org/10.9744/dimensi.42.2.51-58. 